\title{
Stereochemical Investigation of a Novel Biological Active Substance from the Secondary Metabolites of Marine Fungus Penicillium chrysogenum SYP-F-2720
}

\author{
Linwei Li, ${ }^{1}$ Yalu Zhang, ${ }^{1}$ Zhen $\mathrm{Li}^{1}{ }^{1}$ Zhiguo $\mathrm{Yu},{ }^{2}$ and Tiemin $\mathrm{Sun}^{1, *}$ \\ ${ }^{1}$ Key Laboratory of Structure-Based Drug Design and Discovery, Shenyang Pharmaceutical University, Ministry of Education. \\ Shenyang 110016, PR China. suntiemin@126.com \\ 2 Pharmacy Department, Shenyang Pharmaceutical University. Shenyang 110016, PR China.
}

Received November 11 ${ }^{\text {th }}, 2014$; Accepted December $4^{\text {th }}, 2014$

\begin{abstract}
The chemical structure and absolute configuration of a novel benzoic acid (1) which is the secondary metabolites from the marine fungus Penicillium chrysogenum SYP-F-2720, has been determined by experimental spectroscopic data and quantum chemical calculations of its electronic circular dichroism (ECD). The configurational assignments were further confirmed by the highly consistent spectra between natural compound and synthetic compound which from raw material with a definite configuration. Furthermore, The target compound exhibited more significant anti-inflammatory and analgesic activities than aspirin when administered at $100 \mathrm{mg} / \mathrm{kg}$, however, it behaved no ulcerogenic effect.

Key words: (S)-2-(2-hydroxypropanamido) Benzoic Acid, Structural Elucidation, DFT, ECD, Anti-inflammatory.
\end{abstract}

\section{Introduction}

The secondary metabolites of marine microorganisms is fairly recognized as a potential source of original structure and biological activity substance due to its strain-specific [1-5]. Marine fungus is a class of marine microorganisms, and its secondary metabolites demonstrate biodiversity [6]. As the most primitive multicultural marine fungus organisms, sponge is an important source of natural active ingredients [7, 8]. To data, numerous novel biological active substance with antitumor, antiviral, antibacterial, anti-inflammatory, and enzyme inhibitory activities have been isolated from sponge-derived marine fungus, such as aspergione A-F from Aspergillus versicolor, evariquinone and isoemericellin from Emericella variecolor, isocyclocitrinol A from Penicillium citrinum, sorbicillactones A from Penicillium chrysogenum [7-12]. SYP-F-2720 is a sponge-derived marine fungus belongs to $P$. chrysogenum strain, which is no relevant research on it so far. In the course of a program aiming at the isolation of secondary metabolites from the fermentations of $P$. chrysogenum, a novel benzoic acid (compound $\mathbf{1}$ ) was recently isolated from the secondary metabolites of $P$. chrysogenum SYP-F-2720 together with three known compounds, cycol-(ProLeu), cyclo-(4-hydroxyl-Pro-Phe), (22E,24R)-Ergosta-5,7,22triene-3 $\beta$-ol [13-15]. Yet its absolute configuration remained unknown. Herein, we describe the absolute stereochemistry of compound 1 by means of experimental spectroscopic data and quantum chemical calculations. Configuration assignment of the target compound was further verified by synthetic compound which from raw material with a definite configuration.
Resumen. Se determinó la estructura química y la configuración absoluta de un ácido benzoico novedoso (1), presente en los metabolitos secundarios del hongo marino Penicillium chrysogenum SYP-F-2720. La determinación se llevó a cabo mediante datos espectroscópicos experimentales y cálculos químicos cuánticos de su dicroísmo circular electrónico (DCE). La asignación de la configuración se confirmó mediante la comparación de los espectros del compuesto natural y el correspondiente compuesto sintético. Además, el compuesto aislado exhibe actividades anti-inflamatorias y analgésicas más significativas que la aspirina cuando se administró a una dosis de $100 \mathrm{mg} / \mathrm{kg}$, y no mostró ningún efecto ulcerogénico.

Palabras clave: (S)-2-(2-hidroxipropanamido) Benzoico, elucidación estructural, DFT, ECD, antiinflamatorio.

Furthermore, the anti-inflammatory and analgesic activities of 1 were evaluated.

\section{Results and Discussion}

The chemical structure of compound 1 (Fig. 1) was elucidated by a more detailed ${ }^{1} \mathrm{H}$ and ${ }^{13} \mathrm{C}$ NMR spectroscopic analysis via ${ }^{1} \mathrm{H}-{ }^{1} \mathrm{H}$ COSY, HMBC, HSQC and DEPT experimental finding (Table 1). ${ }^{1} \mathrm{H}$ NMR spectrum of compound 1 implied that four aromatic proton signals at $\delta_{\mathrm{H}} 7.17(\mathrm{td}, J=7.8,1.2$ $\mathrm{Hz}), 7.61(\mathrm{td}, J=7.8,1.2 \mathrm{~Hz})$ and $\delta 8.01(\mathrm{dd}, J=7.8,1.2$ $\mathrm{Hz}$ ), 8.71 (dd, $J=7.8,1.2 \mathrm{~Hz}$ ) which were assigned to a an ortho-substituted benzene ring, besides, two hydroxyl groups at $\delta_{\mathrm{H}} 6.13\left(2^{\prime}-\mathrm{OH}, \mathrm{s}\right)$ and $\delta_{\mathrm{H}} 11.99(\mathrm{COOH}, \mathrm{s})$, one methine $\left(\delta_{\mathrm{H}} 4.16, \mathrm{~m}\right)$, one methyl group $\left(\delta_{\mathrm{H}} 1.34, \mathrm{~d}\right)$ and amino proton at $\delta_{\mathrm{H}} 13.55$ were also detected. The fact that the carboxylic acid group connected to the phenyl group was confirmed by the resonance at $\delta \mathrm{c} 168.9 \mathrm{ppm}$ in the ${ }^{13} \mathrm{C} \mathrm{NMR}$, the absorption

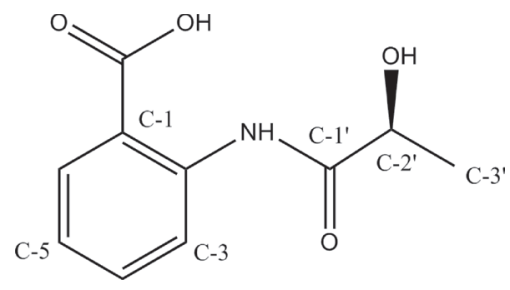

Fig. 1. Chemical structure of compound $\mathbf{1}$. 
Table 1. ${ }^{1} \mathrm{H}$ NMR and ${ }^{13} \mathrm{C}$ NMR data of compound 1 (DMSO, $\delta$, ppm, $J / \mathrm{Hz})$.

\begin{tabular}{llll}
\hline Atom & ${ }^{1} \mathrm{H}$ NMR & ${ }^{13} \mathrm{C}$ NMR & HMBC $(\mathrm{H} \rightarrow \mathrm{C})$ \\
\hline 1 & & $116.5(\mathrm{C})$ & \\
2 & & $140.5(\mathrm{C})$ & \\
3 & $8.71(\mathrm{~d}, J=7.8 \mathrm{~Hz})$ & $119.5(\mathrm{CH})$ & 168.9 \\
4 & $7.61(\mathrm{dd}, J=7.8,1.2 \mathrm{~Hz})$ & $134.0(\mathrm{CH})$ & \\
5 & $7.17(\mathrm{dd}, J=7.8,1.2 \mathrm{~Hz})$ & $122.6(\mathrm{CH})$ & \\
6 & $8.01(\mathrm{~d}, J=7.8 \mathrm{~Hz})$ & $131.3(\mathrm{CH})$ & 168.9 \\
$\mathrm{COOH}$ & $11.99(\mathrm{~s})$ & $168.9(\mathrm{C})$ & \\
$\mathrm{NH}$ & $13.55(\mathrm{~s})$ & & \\
$1^{\prime}$ & & $174.4(\mathrm{C})$ & \\
$2^{\prime}$ & $4.16(\mathrm{~m})$ & $68.0(\mathrm{CH})$ & $20.9,174.4$ \\
$2^{\prime}-\mathrm{OH}$ & $6.13(\mathrm{~s})$ & & \\
$3^{\prime}$ & $1.34(\mathrm{~d}, J=6.6 \mathrm{~Hz})$ & $20.9\left(\mathrm{CH}_{3}\right)$ & $68.0,174.4$ \\
\hline
\end{tabular}

bands at 3400.4 and $1660.6 \mathrm{~cm}^{-1}$ in IR spectrum, which suggested a conjugated nature, and also supported by the HMBC correlation between $\mathrm{H}-3, \mathrm{H}-6$ and $\delta \mathrm{c} 168.9$. The ${ }^{1} \mathrm{H}-{ }^{1} \mathrm{H}$ COSY spectrum of the title compound demonstrated the presence of two spin systems (H-2'-H3-3' and H-2'-H-2'-OH) (Fig. 2). Associated with the HMBC correlations between $\mathrm{H}-3^{\prime}$ and C-2', 1', $\mathrm{H}-2$ ' and C-3', 1' illustrated the presence of $\mathrm{CH}_{3^{-}}$ $\mathrm{CH}-\mathrm{C}=\mathrm{O}$. The structure assigned to $\mathbf{1}$ was also confirmed by its HR-EI-MS $\left(m / z[\mathrm{M}+\mathrm{Na}] 232.0580\right.$, calcd for $\mathrm{C}_{10} \mathrm{H}_{11} \mathrm{O}_{4} \mathrm{~N}$ 209.0581).

The stereochemistry assignment of compound $\mathbf{1}$ was determined by electronic circular dichroism (ECD) spectra provided

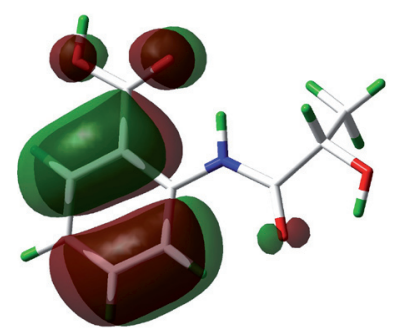

MO 54

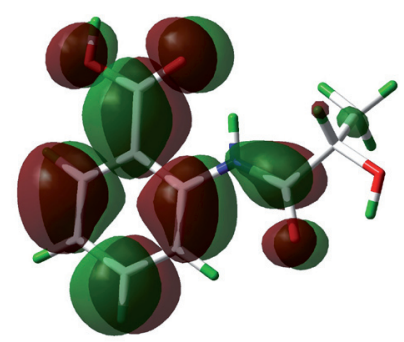

MO 56 LUMO

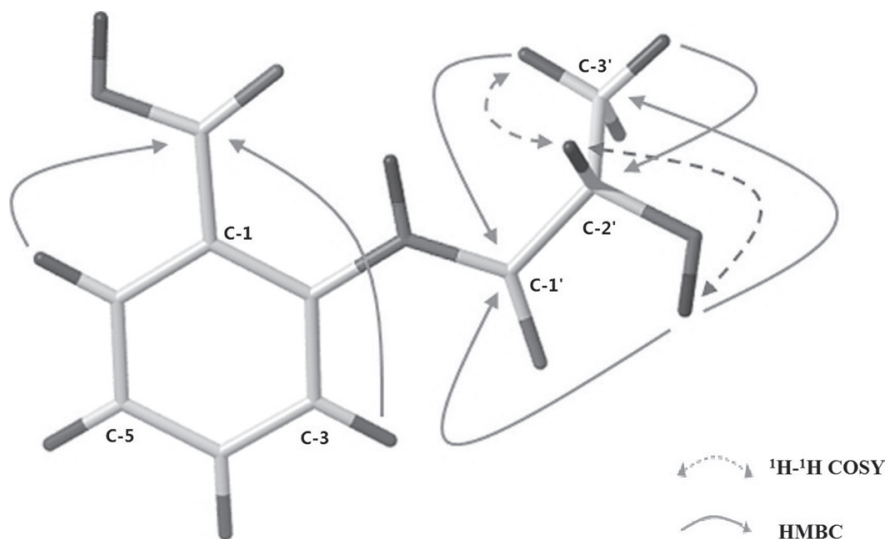

Fig. 2. Key ${ }^{1} \mathrm{H}-{ }^{1} \mathrm{H}$ COSY and $\mathrm{HMBC}$ correlations of compound $\mathbf{1}$.

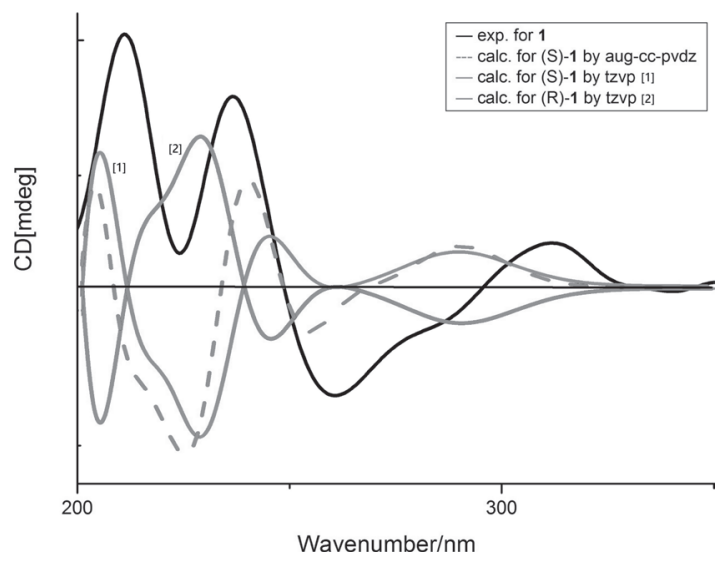

Fig. 3. Calculated and experimental ECD of compound $\mathbf{1}$.

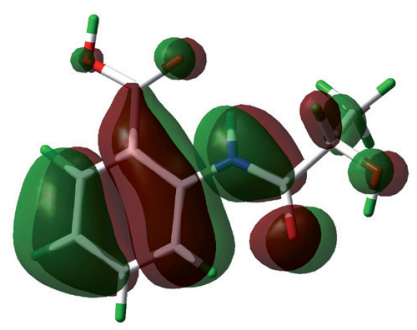

Мо 55 номо

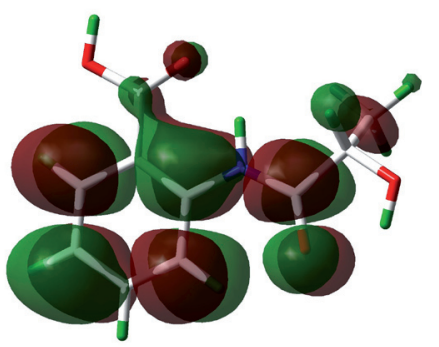

MO 57

Fig. 4. The most important orbitals of the optimized conformer of (S)-1. 


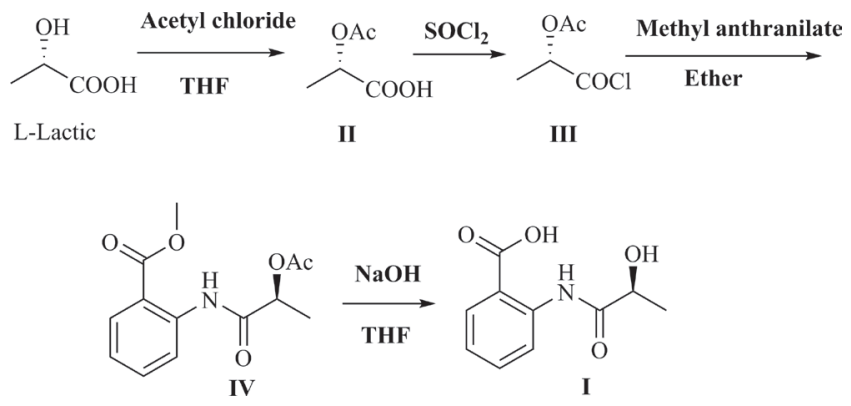

Scheme 1. Reagents and conditions: (1) acetyl chloride and L-Lactic, THF, r.t. for $3 \mathrm{~h}$; (2) thionyl chloride and (R)-2-acetoxypropanoic acid; (3) methyl anthranilate and (R)-1-chloro-1-oxopropan-2-yl acetate, ether, $-5{ }^{\circ} \mathrm{C}, 30 \mathrm{~min}$; (4) $\mathrm{NaOH}$ and methyl (S)-2-(2-acetoxypropana mido)benzoate, THF and $\mathrm{MeOH}$, r.t., $3 \mathrm{~h}$.

by measured and quantum chemical calculations which carried out by TD-DFT/CAM-B3LYP/TZVP [16, 17]. The spectrum simulated for (S)-1, reproduced the sign and intensity of measured positive $C E$ at 237 and negative $C E$ at $261 \mathrm{~nm}$, is in excellent agreement with the experimental pattern. On the contrary, the calculated ECD spectrum for (R)-1 was almost opposite to the experimental curve of (S)-1. Thus, the absolute configuration of 1 was assigned to $S$.

In order to get reliable results, TD-DFT/CAM-B3LYP/ aug-cc-pVDZ ECD calculations were also performed for the conformers of (S)-1 [18]. The Boltzmann-weighted ECD of (S)-1 by different basis sets did not lead to notable changes in the ECD curve profile (Fig. 3).

The origin of the CEs in the experimental ECD of 1 could be explained by molecular orbital (MO) analysis at the same level of ECD calculation (Fig. 4). As inferred from the MO analysis, the significant positive $\mathrm{CE}$ at $211 \mathrm{~nm}$ was contributed by the electronic transition (ET) from MO 54 to MO 57 involving the $\pi \rightarrow \pi^{*}$ transition of phenyl ring and carbonyl group $\mathrm{n} \rightarrow$ $\pi^{*}$ transition. The positive $\mathrm{CE}$ at $237 \mathrm{~nm}$ is mainly dominated by transitions from MO 54/MO 56 (50\%) and MO 55/MO 57 (42\%), which could be ascribed to the combination of a benzene ring $\pi \rightarrow \pi^{*}$ transition and the $n \rightarrow \pi^{*}$ transition of amide and hydroxy groups. Moreover, the strong negative CE at 261 $\mathrm{nm}$ in the measured spectrum also derived from the same ET which causing the $\mathrm{CE}$ at $237 \mathrm{~nm}$. According to the above data, it was suggested that the CEs at 211,237, 261 and $312 \mathrm{~nm}$ in

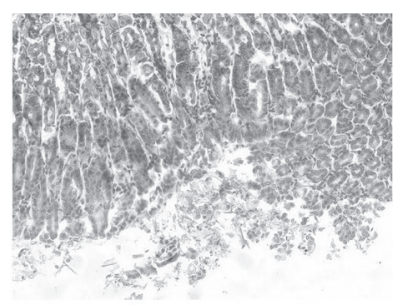

(a)

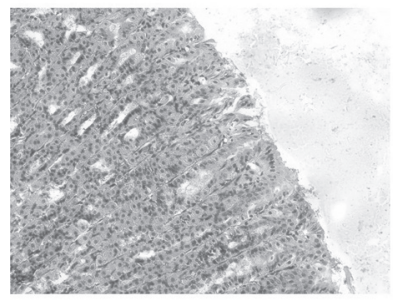

(c)

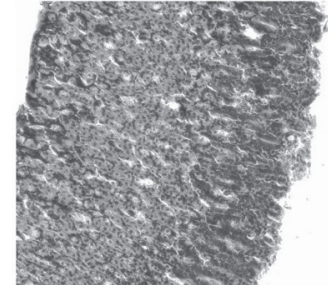

(b)

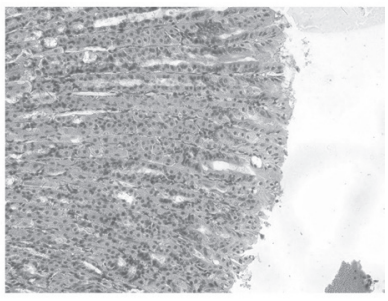

(d)
Fig. 5. The stomach tissue biopsy of the positive control and test groups. ( $\mathrm{a}, \mathrm{b}=$ positive control group; $\mathrm{c}, \mathrm{d}=$ test group).

the ECD curve were determined by the configurational assignment of C-2', which was in accordance with the theoretical ECD spectra for the two stereisomrs of (R and $\mathrm{S}$ ).

In our research, compound $\mathbf{1}$ has been synthesized from commercially available chiral precursors. Synthetic compound presented remarkable similar spectroscopic parameters to compound 1, particularly ECD spectral features (Fig. 3). The synthetic procedure of compound $\mathbf{1}$ is shown in Scheme 1.

On the basis of the above evidence, the complete structure of compound 1 was elucidated as (S)-2-(2-hydroxypropanamido) benzoic acid.

The anti-inflammatory, analgesic as well as the ulcerogenic activities of compound $\mathbf{1}$ was investigated in vivo at 100 $\mathrm{mg} / \mathrm{kg}$ dosage and compared with aspirin as reference standard in all screenings. It is clearly seen from Fig. 5 that the positive control group ( $a$ and $b$ ) demonstrates ulcerogenic and bleeding points, versus test group (c and d); in addition, data showed in Table 2 indicated that compound $\mathbf{1}$ exhibits considerable antiinflammatory and analgesic activities compared with aspirin, indicating that it is an active substance with anti-inflammatory and analgesic pharmacological activity.

Table 2. Anti-inflammatory, analgesic and ulcerogenic activities of compound $\mathbf{1}(100 \mathrm{mg} / \mathrm{kg}){ }^{\mathrm{a}}$

\begin{tabular}{llll}
\hline Compound & Anti-inflammatory activity & Analgesic activity & Ulcerogenic activity \\
\hline & Swelling rate $(\%)$ & Number of writhing & Lesion index $(\mathrm{mm})$ \\
Control $^{\mathrm{b}}$ & $242.6 \pm 31.6$ & $31.9 \pm 12.6$ & $0.0 \pm 0.0$ \\
Aspirin & $193.7 \pm 27.4^{* *}$ & $7.3 \pm 9.0^{* *}$ & $4.0 \pm 0.5$ \\
$\mathbf{1}$ & $191.0 \pm 47.7^{* *}$ & $12.6 \pm 9.9^{* *}$ & $0.0 \pm 0.0^{* * *}$ \\
\hline
\end{tabular}

${ }^{a}$ Values represent the mean \pm S.E. of ten rats for each group. Oral administration for all test compounds.

${ }^{\mathrm{b}}$ Control group animals were given suspension of $0.5 \%$ methylcellulose.

${ }^{* *} \mathrm{P}<0.01$, Student's t-test vs. control, ${ }^{* * *} \mathrm{P}<0.001$, Student's t-test vs. aspirin. 


\section{Experimental}

\section{General experimental procedures}

NMR spectra were recorded on Bruker AVANCE-600 NMR spectrometer, TMS as internal standard, $\delta$ in ppm, $J$ in $\mathrm{Hz}$. ${ }^{13} \mathrm{C}$ multiplicities were determined by DEPT spectra. COSY, HMBC, HSQC and DEPT experiments were performed using Bruker microprograms. The optical rotation degree was measured PERKIN-ELMER241M optical rotation spectrometer, CD spectrum was recorded on Biologic MOS-450 CD spectrometer. The IR spectrum was recorded in the region 4000-400 $\mathrm{cm}^{-1}$ using $\mathrm{KBr}$ pellet technique with $1.0 \mathrm{~cm}^{-1}$ resolution on a BRUKER IFS-55V IR spectrometer. The FT-Raman spectra was recorded using $1064 \mathrm{~nm}$ line of Nd:YAG laser as the excitation wavelength in the region $3500-100 \mathrm{~cm}^{-1}$ on a BRUKER RFS 100/S FT-Raman spectrometer. The detector was liquid nitrogen cooled Ge detector. Two hundred scans were accumulated at $4 \mathrm{~cm}^{-1}$ resolution with $50 \mathrm{~mW}$ laser power. Mass spectra were measured on Shimadzu 2010 LC-MS and a Bruker ESI-Q-TOF-MS/MS high-resolution mass spectrometer. Column chromatography was performed on silica gel (200-300 mesh; Qingdao Haiyang Chemicals).

\section{Fungal materials}

SYP-F-2720 is a sponge-derived marine fungus which belongs to Penicillium strains collected in 2003, Off the North Sea coast, China and deposited in School of Life Sciences, Shenyang Pharmaceutical University, China. The strain was maintained on Yeast extract-Malt extract Agar medium (0.09 $\mathrm{g}$ yeast extract powder, $0.09 \mathrm{~g}$ malt immersion powder, $0.15 \mathrm{~g}$ peptone, $0.3 \mathrm{~g}$ glucose, $0.45 \mathrm{~g}$ agar and $0.9 \mathrm{~g} \mathrm{NaCl}$ in $30 \mathrm{~mL}$ distilled water) and cultivated at $28{ }^{\circ} \mathrm{C}$ for 5 days. Mycelial agar plugs were inoculated into a $2000 \mathrm{~mL}$ Erlenmeyer flask containing sterilized (glucose $1 \%$, peptone $0.5 \%$, yeast extract powder $0.3 \%$, malt immersion powder $0.3 \%, \mathrm{NaCl} 3 \%$ in 700 $\mathrm{mL}$ distilled water) at $28^{\circ} \mathrm{C}$ for 14 days.

\section{Extraction and Isolation}

The fermentation broth of SYP-F-2720 was extracted by adding $1400 \mathrm{~mL}$ ethyl acetate (EtOAc) to the flask and then homogenized. The homogenized suspensions were collected, filtrated, and partitioned with water. Ethyl acetate portion was evaporated under reduced pressure to give brown syrup $(0.1 \mathrm{~g})$. Then the syrup was subjected to octadecylsilyl (ODS) column with linear gradient elution with $40 \%-100 \%$ aqueous methanol and 61 fractions were obtained. Fractions 1-4 were chromatographed with preparative-HPLC $\left(\mathrm{MeOH}-\mathrm{H}_{2} \mathrm{O} 40: 60\right)$ to produce compound $\mathbf{1}(1 \mathrm{mg})$.

\section{Synthesic procedures of compound 1}

Acetyl chloride $(19.2 \mathrm{~mL}, 266.6 \mathrm{mmol})$ was added to the solution of L-Lactic (12.0 g, $133.3 \mathrm{mmol})$ and tetrahydrofuran (24
$\mathrm{mL}$ ) at $-5^{\circ} \mathrm{C}$, then the solution was stirred at room temperature for $5 \mathrm{~h}$. The solution was evaporated under reduced pressure to obtain intermediate II which as colorless oily liquid (14.6 g, 83.6\%). Then, the reaction mixture refluxed at $50{ }^{\circ} \mathrm{C}$ for $2 \mathrm{~h}$ after added thionyl chloride (48 $\mathrm{mL}$ ) to II (14.6 g, $110.6 \mathrm{mmol})$, and evaporated under reduced pressure to gain intermediate III which as light yellow oily liquid (15.6 g, 93.7\%). Next, added the anhydrous ether solution of III (III: $15.6 \mathrm{~g}, 103.7 \mathrm{mmol}$, anhydrous ether: $25 \mathrm{~mL}$ ) to the solution of methyl anthranilate $(60.0 \mathrm{~g}, 395.8 \mathrm{mmol})$ and anhydrous ether $(150 \mathrm{~mL})$ at $-5^{\circ} \mathrm{C}$, and stirred for $3 \mathrm{~h}$, filtered. The filtrate was washed by $\mathrm{HCl}$ $(100 \mathrm{~mL} \times 6,1 \mathrm{~mol} / \mathrm{L}), \mathrm{H}_{2} \mathrm{O}(100 \mathrm{~mL} \times 3)$ and $\mathrm{NaCl}(100$ $\mathrm{mL} \times 3)$, dried by anhydrous sodium sulphate, filtered and concentrated to acquire intermediate IV which as pale yellow crystalline (24.7 g, 89.9\%). The sodium hydroxide solution (1 $\mathrm{mol} / \mathrm{L})$ was slowly dropped into the mixture of intermediate IV (12.7 g, $47.92 \mathrm{mmol})$, tetrahydrofuran $(60 \mathrm{~mL})$ and methanol $(40 \mathrm{~mL})$, and then stirred for $3 \mathrm{~h}$ at room temperature. Next, the reaction solution was extracted with $\mathrm{CH}_{2} \mathrm{Cl}_{2}(200 \mathrm{~mL} \times$ 3 ), and then adjusted the $\mathrm{pH}$ of the aqueous phase to 2 with $\mathrm{HCl}(1 \mathrm{~mol} / \mathrm{L})$, standing for crystallization, filtrated, and dried to afford (S)-2-(2-hydroxypropanamido)benzoic acid (8.79 g, $87.8 \%$ ).

\section{(S)-2-(2-hydroxypropanamido) benzoic acid}

White needle crystals; $[\alpha]-15.6^{\circ}(c, 0.10, \mathrm{MeOH})$; IR spectrum $\left(\mathrm{KBr}, v_{\max }, \mathrm{cm}^{-1}\right)$ : 3400, 3267, 1689, 1660,1584, $1530,1450,1402,1293,1264,1127,876,756 ; \mathrm{MS}(\mathrm{ESI}): \mathrm{m} / z$ $=232.0582[\mathrm{M}+\mathrm{Na}] ;{ }^{1} \mathrm{H}$ NMR $(600 \mathrm{MHz}, \mathrm{DMSO}, \delta): \delta_{\mathrm{H}}$ $13.55(1 \mathrm{H}, \mathrm{s}, \mathrm{NH}), 11.99(1 \mathrm{H}, \mathrm{s}, \mathrm{COOH}), 8.71\left(\mathrm{~d}, J_{3,4}=7.8\right.$ $\mathrm{Hz}, \mathrm{H}-3), 8.01$ (d, $\left.J_{5,6}=7.8 \mathrm{~Hz}, \mathrm{H}-6\right), 7.61$ (dd, $J_{3,4}=7.8, J_{4,6}=$ $1.2 \mathrm{~Hz}, \mathrm{H}-4), 7.17$ (dd, $\left.J_{5,6}=7.8, J_{3,5}=1.2 \mathrm{~Hz}, \mathrm{H}-5\right), 6.13(1 \mathrm{H}$, s, 2'-OH), 4.16 (1H, m, H-2'), 1.34 (d, $\left.J=6.6 \mathrm{~Hz}, \mathrm{CH}_{3}\right) .{ }^{13} \mathrm{C}$ NMR (150 MHz, DMSO, $\delta): \delta \mathrm{c} 174.4$ (C-1'), $168.9(\mathrm{COOH})$, 140.5 (C-2), 134.0 (C-4), 131.3 (C-6), 122.6 (C-5), 119.5 (C-3), 116.5 (C-1), 68.0 (C-2'), 20.9 (C-3'), see Table 1.

\section{Computational details}

The conformational searching for a pair of enantiomers ( $R$ and S) was performed by Spartan 10 program with MMFF molecular mechanics force field $[19,20]$. After surveying the conformational space, the conformers within $5 \mathrm{kcal} / \mathrm{mol}$ enegy window were re-optimized at B3LYP level of theory using 6$311++\mathrm{G}(2 \mathrm{~d}, 2 \mathrm{p})$ basis sets under PCM model by Gaussian 09 package program [21-23].

The Gibbs free energies were also calculated at the same level and frequency calculations based on the previously optimized geometries in order to ensure the minimum energy of the structure. Relative population of each conformer was valued on the basis of Boltzmann weighting factor at $298 \mathrm{~K}$ to simulate ECD. The Boltzmann weighting factor $P_{i}\left(P_{i}=\frac{\exp \left(-G_{i} / R T\right)}{\sum_{j} \exp \left(-G_{j} / R T\right)} \times 100 \%\right)$, where $\mathrm{G} i, R$ and $T$ stand 
for the Gribbs free energy, gas constant and absolute temperature $(298 \mathrm{~K})$.

The ECD were simulated by the time-dependent density functional theory (TDDFT) method at CAM-B3LYP/TZVP and CAM-B3LYP/aug-cc-pvdz basis set, and methanol was used as solution under PCM model. ECD curves were generated by Specdis with half bandwidth of $0.32 \mathrm{eV}[16,18$, 19].

\section{Biological activity assay}

The anti-inflammatory and analgesic activities associated with the ulcerogenic assay of compound $\mathbf{1}$ were ascertained compared with aspirin which was used as positive control. The xylene-induced mouse ear edema model, acetic acid-induced writhing response model, and influence on the gastric irritation, following the reported method [24-29]. Pharmacological tests were conducted in Kunming mice weighing 20-25 g, and they were divided into nine groups of 10 mice each, of which three groups were all male mice for evaluating anti-inflammatory activity, three groups were all female mice for testing analgesic activity, the other three groups were either sex for evaluating ulcerogenic activity, pregnant female mice were excluded. Animal room was maintained at $25 \pm 2{ }^{\circ} \mathrm{C}$ with a 12 hours light/dark cycle. Food and tap water was freely available except for the acute ulcerogenesis test. All test compounds were suspended in a solution of methylcellulose $(0.5 \%)$ and administered orally at the dose of $100 \mathrm{mg} / \mathrm{kg}$ body weight. The results were summarized in Table 2. The ethical guidelines described in the NIH Guide for Care and Use of Laboratory Animals were followed throughout the experiments.

\section{Conclusions}

In summary, this paper reports the isolation and structural identification of (S)-2-(2-hydroxypropanamido) benzoic acid which was isolated from the fermentations of Penicillium chrysogenum SYP-F-2720. The structure with absolute configuration was determined by spectroscopic data coupled with quantum chemical calculations. Furthermore, the structural elucidation as well as AC was confirmed by the strong correlation of spectra between compound $\mathbf{1}$ and synthetic compound $\mathbf{1}$ which from raw material with a definite configuration. The anti-inflammatory and analgesic activities of the compound were evaluated and no ulcerogenic activity was observed simultaneously. Taken together, the results provide a new active substance which has anti-inflammatory and analgesic pharmacological activity.

\section{Acknowledgements}

This work was supported by the National Fund for Talent Training in Basic Science (No.J1103606), Program for Innovative Research Team of the Ministry of Education and
Program for Liaoning Innovative Research Team in University. The theoretical calculations were conducted on the ScGrid and Deepcomp7000 the Supercomputing Center, Computer Network Information Center of Chinese Academy of Sciences.

\section{References}

1. Blunt, J. W.; Copp, B. R.; Munro, M. H. G.; Northcote, P. T.; Prinsep, M. R. Nat. Prod. Rep. 2006, 23, 26-78.

2. Donia, M.; Hamann, M. T. Lancet. 2003, 3, 338-348.

3. Bugni, T. S.; Ireland, C. M. Nat. Prod. Rep. 2004, 21, 143-163.

4. Saleem, M.; Ali, M. S. S.; Hussain, J. A.; Ashraf, M.; Lee, Y. S. Nat. Prod. Rep. 2007, 24, 1142-1152.

5. Venkateswarlu, Y.; Srinivasa, R. N.; Venkatesham, U. Chem Biomed Appl. 2001, 6, 101-128.

6. Boot, C. M; Amagata, T; Tenney, K; Compton, J. E; Pirtraszkiewicz, H; Valeriote. F. A; Crews. P. Tetrahedron. 2007, 63, 99039914.

7. Li, Q.; Wang, G. Microbiol Res, 2004, 52, 67-100.

8. Wu, B. W.; Hu, Y. H.; Fang, Z. J. Chin. Mar. Drugs. 2006, 25, 39-43.

9. Walter, C.; Christopher, N.; Catherine, H. J. Methods 2007, 42, 358-376.

10. Lin, W. H.; Fu, H. Z.; Li, J. Chin. Chem. Lett. 2001, 12, $235-$ 238.

11. Gao, S. S.; Li, X. M.; Du, F. Y.; Li, C. S.; Proksch, P.; Wang, B. G. Drugs, 2011, 9, 59-70.

12. Bugni, T. S.; and Ireland, C. Nat. Prod. Rep. 2004, 21, 143-163.

13. Wang, J. J.; Zhao, Y. L.; Men, L.; Zhang, Y. X.; Liu, Z.; Sun, T. M.; Geng, Y. D.; Yu, Z. G. Chem. Nat. Compd. 2014, 50, 405407.

14. Yu, Z.G; Zhao, Y.L; Wang, J.J. Chian patent, 201210541957.8, 2014. (CN 103864638 A).

15. Guan, J.; Zhao, Y. L.; Zhu, H. Y.; An, Z. Z.; Yu, Y. M.; Li, R. J.; Yu, Z. G. J. Pharm. Biomed. 2014, 95, 20-25.

16. Harada, N.; Nakanishi, K.; Circular dichroic spectroscopy: exciton coupling in organic stereochemistry, University Science Books, Mill Valley, 1983.

17. Giuseppe Mazzeo, G.; Santoro, E.; Andol, A.; Cimmino, A.; Troselj, P.; Petrovic, A. G.; Superchi, S.; Evidente, A.; Berova, N. J. Nat. Prod. 2013, 76, 588-599.

18. Miertuš, S.; Tomasi, J.; J. Chem. Phys. 1982, 65, 239-245.

19. Spartan 08, Wavefunction Inc., Irvine, CA 92612, USA, 2008.

20. Berova, N.; Nakanishi, K.; Woody R. W. Circular dichroism: Principles and Applications, $2^{\text {nd }}$ ed.; Wiley-VCH, NewYork, USA, 2000.

21. Miertuš, S.; Scrocc, E.; Tomasi, J. J. Chem. Phys. 1982, 55, $117-$ 129.

22. Evidente, A.; Superchi, S.; Cimmino, A.; Mazzeo, G.; Mugnai, L.; Rubiales, D.; Andol, A. Eur. J. Org. Chem. 2011, 5564-5570.

23. Frisch, M. J.; Trucks, G. W.; Schlegel, H. B.; Scuseria, G. E.; Robb, M. A.; Cheeseman, J. R.; Scalmani, G.; Barone, V.; Mennucci, B.; Petersson, G. A.; Nakatsuji, H.; Caricato, M.; Li, X.; Hratchian, H. P.; Izmaylov, A. F.; Bloino, J.; Zheng, G.; Sonnenberg, J. L.; Hada, M.; Ehara, M.; Toyota, K.; Fukuda, R.; Hasegawa, J.; Ishida, M.; Nakajima, T.; Honda, Y.; Kitao, O.; Nakai, H.; Vreven, T.; Montgomery, J. A., Jr.; Peralta, J. E.; Ogliaro, F.; Bearpark, M.; Heyd, J. J.; Brothers, E.; Kudin, K. N.; Staroverov, V. N.; Kobayashi, R.; Normand, J.; Raghavachari, K.; Rendell, A.; Burant, J. C.; Iyengar, S. S.; Tomasi, J.; Cossi, M.; Rega, N.; Millam, M. J.; Klene, M.; Knox, J. E.; Cross, J. B.; Bakken, V.; Adamo, C.; Jaramillo, J.; Gomperts, R.; Stratmann, R. E.; Yazyev, O.; Austin, A. J.; Cammi, R.; Pomelli, C.; Ochterski, J. W.; Martin, R. L.; Morokuma, K.; Zakrzewski, V. G.; Voth, G. 
A.; Salvador, P.; Dannenberg, J. J.; Dapprich, S.; Daniels, A. D.; Farkas, Ö.; Foresman, J. B.; Ortiz, J. V.; Cioslowski, J.; Fox, D. J.; Gaussian 09, Revision C.01, Gaussian, Inc., Wallingford CT, 2010.

24. Romay, C.; Armesto, J.; Remirez, D.; Gonzalez, R.; Ledon, R.; Garcia, N. J. Inflamm. Res. 1998, 47, 334-348.

25. Gu, K.; Bi, L.; Zhao, M.; Wang, C.; Kao, M.; Tok, J.; Peng, S. Bioorg. Med. Chem. 2006, 14, 1339-1347.
26. Bi, L.; Zhang, Y.; Wang, M.; Tok, C.; Peng, J. Bioorg. Med. Chem. 2005, 13, 5640-5646.

27. Siegmund, E. A.; Cadmus, R. A.; Lu, G. Proc. Soc. Exp. Biol. Med. 1957, 95, 729-731.

28. Verma, M.; Sinha, J. N.; Gujrati, V. R. Pharmacol. Res. Commun.1981, 13, 967-979.

29. Suleyman, H.; Akcay, F.; Altinkaynak, K. Pharmacol. Res. 2002, $45,155-158$ 